\title{
The Role Realization and Its Relationship with Personal Responsibility among the Trainee Counselors
}

\author{
Basem Mohammed Al-Frehat ${ }^{1, *}$, Ali Saleh Jarwan ${ }^{2}$, Rami Abdallah Tashtoush ${ }^{2}$, \\ Alaaaddeen Mohammad Obaidat ${ }^{2}$ \\ ${ }^{1}$ Department of Educational Sciences, Ajloun University College, Al Balqa Applied University, Jordan \\ ${ }^{2}$ Department of Counselling and Educational Psychology, Faculty of Education, Yarmouk University, Jordan
}

Received August 23, 2020; Revised September 29, 2020; Accepted October 24, 2020

\section{Cite This Paper in the following Citation Styles}

(a): [1] Basem Mohammed Al-Frehat, Ali Saleh Jarwan, Rami Abdallah Tashtoush, Alaaaddeen Mohammad Obaidat, "The Role Realization and Its Relationship with Personal Responsibility among the Trainee Counselors," Universal Journal of Educational Research, Vol. 8, No. 11B, pp. 6313 - 6326, 2020. DOI: 10.13189/ujer.2020.082271

(b): Basem Mohammed Al-Frehat, Ali Saleh Jarwan, Rami Abdallah Tashtoush, Alaaaddeen Mohammad Obaidat (2020). The Role Realization and Its Relationship with Personal Responsibility among the Trainee Counselors. Universal Journal of Educational Research, 8(11B), 6313 - 6326. DOI: 10.13189/ujer.2020.082271.

Copyright $\bigcirc 2020$ by authors, all rights reserved. Authors agree that this article remains permanently open access under the terms of the Creative Commons Attribution License 4.0 International License

\begin{abstract}
The study aimed to identify the levels of realization of the role and personal responsibility among trainee counselors. It also highlighted the relationship between them to know the differences between the levels of the role realization and personal responsibility according to the academic achievement variable. To achieve this, they conducted the study upon (132) male and female trainee counselors who were selected by the intentionally randomized method. The researchers applied the two scales of the role realization and personal responsibility to the study sample. The researchers developed the role realization scale by making use of the tasks and duties of the educational counselor in the Jordanian Ministry of Education. Also, the researchers used the scale of personal responsibility prepared by (Ali and Ahmad, 2016) [5] to comprise 24 items. The results showed that the levels of the role realization and personal responsibility of the trainee counselors were at a high level. And there was no statistically significant difference between the levels of the role realization and personal responsibility because of the academic achievement variable. Besides, the results showed the existence of a statistically significant positive relationship between the role realization and personal responsibility of the trainee counselors.
\end{abstract}

Keywords Personal Responsibility, The Role Realization, Trainee Counselors

\section{Introduction}

The counseling process depends on important considerations, including the role realization the counselor plays in the educational institution. Weak realization of the role of the psychological counselor leads to multiple problems. These problems include duplication of roles, poor structured communication, and the difficulty of evaluating performance as an essential aspect in the work's development of the psychological counselor [26]. The poor counselors' realization of their roles also affects their relationships and interactions with others. Poor role realization has a direct impact on dissatisfaction with the indicative work and low level of job performance [24]. Besides the lack of realization of the psychological counselor of his or her role, function, and tasks lead to multiple problems. These problems include the overlap of the professional reference frameworks for the school principal and faculty members within the educational institution, leading to duplication of opinions and job dissatisfaction [9].

Perceiving the role is one of the most important components in the workplace, and it plays a fundamental role in the performance of the individual. The factors that influence the role can be internal or external. The internal factors include values, beliefs, experiences, needs, and motivations. However, external factors include external attitudes in everyday life [32]. 
Emmanuel [19] has shown that cognitive function is the actual functioning of the role. Therefore, it is concretely focused on the psychological counselor's performance, appearing in his or her behavior, or what happens during his or her performance of counseling tasks. The role realization focuses on performance in the work. Katz and Khan defined it [23] as specific expectations that shape an individual to see himself or herself. They help him, or her, determine the behaviors he or she should perform and the ones to be avoided.

Perceiving the role is people's beliefs about their roles in their jobs and how to do them. The concept of the role can be seen as something that happens within the personality organization. And the individual's interpretation of the role depends on his or her preparations, innate inclinations, motivations, needs, values, and directions. How the individual determines the role, for himself or herself, occurs within the organization of an individual's personality. Hence, the behavior in the social system is determined by how the individual plays this role [38].

Some scholars believe that the personality comprises the roles that a person represents. Others believe that the social personality of the individual comprises composing between the various successive social roles that he or she performs from his or her birth until death [7]. Beena [12] identified three types of roles. First, the expected role refers to the others' expectations coming out from the individual who has the role. Second, the perceived role means the individual's, who has the role, belief in what is expected to be done by him or her. Third, the actual role which shows a specific behavior required to be performed by the individual who has the role.

The individual can perform several roles within the school that needs all kinds of roles to offer successful services. It should be noted that the lack of clarity of the role impedes success in the work. Also, changes in roles lead to severe ambiguity in the role and the emergence of role conflict [14].

St Brice [34] referred to the role practically as being composed of three components. First, a structural component that is represented in the external demands of the role. It is a list of standards, expectations, taboos, and others. Second, a personal component that is an internal aspect on which the individual perceives the social situation. Third, the behavior component of the role is a method by which individuals behave in a particular description.

The role is seen in two aspects. The social side is the individual's expectations about social behavior, such as the expectations of peers, the supervisor, or the employee about his or her employer. The functional aspect is the specific behavior of the individual in his or her work in the educational institution and in performing job tasks [22].

There are four distinct- dimensional types of role realization. First, the breadth of the role which refers to the individual's realization of the behaviors. This kind of role is associated with the specific role as part of one function, or that there are other roles relevant to this job. Second, the effectiveness of the role which shows the individual's realization of his or her competence in performing a certain role effectively, such as help and taking responsibility. Third, the role enhancement means the individual's realization of the existence of a relationship between role performance and the consequences of this performance, such as rewards and punishment. Finally, the role realization refers to the extent to which an individual realizes his or her choice regarding the performance of a particular role [28].

Role theories focus on the roles related to achieving the objectives, organization, and planning of these roles to perform specific tasks, based on the needs of the institution. Roles have titles that have meanings that carry some expectations, obligations, and responsibilities. Also, they offer an internal framework to develop a sense of the meaning of the role and its purpose in that work [31].

The role theory examines the behavior of the individual, especially the social identity in various environments, situations, and situations. Roles help an individual shape the social identity that derives from social interactions with judgment on the messages. These messages are sent from members of the remaining groups, assessing the implications of these interactions and interpreting them to give the sense and value of the interaction [35].

Katz \& Kahn [23] assumes that expectations enhance an individual's realization of the behaviors needed for efficiency. Thus, the role of the individual is determined by a set of specific expectations. If the expectations are insufficient or unclear, the individual does not understand his or her role. This may lead to inefficiency, poor identification of roles with explicit instructions, and uncertainty of the nature or extent of this role, or how to meet the role specifications.

Realizing the counselor's roles and functions help provide the best counseling services for the counselees. It enables others to understand the nature of his or her role and counseling work. And it facilitates collaborating with the psychological counselor and assisting him or her in performing his or her duties for the accurate scientific evaluation of this performance [9].

\section{The Responsibility}

The counselor lives in a world characterized by a rapid change and countless variables that require him or her to, flexibly and successfully, understand and deal with them. Hence, he or she can take responsibility for his or her shoulders. The psychological counselor teaches students to take responsibility on their shoulders [2]. Also, responsibility, whether at the personal or social level, is considered one pillar of mental health. It is a complex feeling of self-confidence and acceptance of others. Thus, 
the counselors who feel the importance of the responsibility imposed on him or her, enjoy high self-reliance, patience, endurance, diligence, and concern among colleagues and society [7].

The concept of responsibility influences the achievement of success. It creates a sense of happiness among counselors who adopt responsible behaviors that lead them to success and progress. Realistic therapy looks at the person with a positive and optimistic view. Glasser believes, too, in the ability of individuals to make their decisions because they are rational, able to solve their problems, responsible for their actions, and behaviors [11].

Glasser [20] defined responsibility as the ability to achieve the needs of the individual in a way that does not deprive others of their ability to achieve their needs and rights. The responsible person is individually independent to have a sense of latent ability to determine what they want from life and responsibly satisfy their needs and objectives. As for Jackson (1994, he defined responsibility as the feeling that generates for the individual that he or she has a mere ethical commitment to other people and society. Thus, a person with a high score feels a sense of commitment to doing the right thing, regardless of personal consequences.

Romo believed that personal responsibility is synonymous with maturity, in the sense that the individual is responsible for himself or herself and towards society. The individual is responsible for all aspects of his or her life situations, experiences, and ideas [33].

Our concept of responsibility is crystallized through what the individual feels regarding all the behavioral and intellectual processes he or she performs. They are an enormous part of him or her to be responsibly born. And if the individual wants to be successful, he or she must be honest with himself or herself, having his or her aspirations and expectations. He or she should not look at others' aspirations and expectations. Besides, he or she should avoid manipulating others by blaming them for what he or she feels and does [6].

Responsibility is one factor that contributes to the integrity of an individual's personality. And it manifests the ability to assume responsibility in many aspects and features. The individual is more sensitive to perform his or her role in social life without inaction or hesitation, being more confident in performing his or her work. And the individual needs to bear the responsibility for choosing the situations that life requires his or her existence without the feeling of having internal conflict in the selection process.

Thus, the individual who has a deep sense of responsibility can make his or her decisions without hesitation or fear of choice. That is because he or she is aware of the role he or she plays in society, as he or she is ready to take responsibility for his or her choice, whatever the results are [4].

There are many criteria, through which the characteristics of responsible behavior are revealed, that state that the responsible individual is reliable, trusted, and loyal. Also, the responsible individual is honest and does not deceive others, bearing responsibility for his or her mistakes, instead of blaming others. He or she has faithfulness and obedience to people he or she belongs to. He or she can finish the works that are given to him or her more accurately, and he or she will bear the responsibility for the results [27].

Personal responsibility depends on the theory of realistic therapy, of which Glasser is the founding father. $\mathrm{He}$ believed that counseling is provided for students via the educator's help given to the counsellee. Hence, he or she can respond positively, satisfying the needs within the concepts of responsibility, realism, and righteousness [8].

The theory of realistic therapy is one of the most effective theories in the preventive aspect of psychological counseling. The objective of education is to help students bear personal responsibility, getting them to the level of responsible behavior. It is the ultimate aim of the educational process and the overall objective of the theory. The relationship between them is characterized by warmth, acceptance, understanding, and focusing on current behavior [17].

The theory of realistic therapy is mainly based on the hypothesis that human beings have five basic needs which are the need for survival, identity, belonging, freedom, and fun. And behavior consists not only of the actions of individuals, but also is described as a general behavior that simultaneously comprised the components of thinking, action, feeling, and entertainment [30].

The theory is based on three basic concepts governing human behavior which are responsibility, reality, and right. Glasser has referred to them by a symbol of (3R) which shows the initials of the words (Responsibility, Reality, Right).

\subsection{Responsibility}

Personal responsibility is a behavior that an individual undertakes to satisfy his or her needs by means that do not contradict others' endeavors of satisfying their needs. The responsible individual is the one who independently seeks to carry out the objectives he or she wishes to achieve by setting them into practice [15]. Personal responsibility is the essence of counseling. The educator who bears personal responsibility is an individual independent person who has the internal psychological support to determine what they want from life. Responsibility helps the individual choose the optimal behavior and self-determination, bearing personal responsibility for his or her actions, way of thinking, and feelings [8].

\subsection{Reality}

This means the current behavior of the individuals and their real emotional experiences and circumstances. The individuals should understand the world in which they live, 
its problems, and obstacles to responsibly achieve their needs within the real limits. Glasser thinks reality determines what we should focus, via the educational process, on the behavior.

\subsection{Correct (Right)}

Personal responsibility is a feeling of pride toward the things that go well with an individual's life. The individual who takes responsibility is the one who controls his or her life and feels happy. Taking personal responsibility requires the individual's courage, the strength of will, and a feeling of control over life [21]. Personal responsibility also helps educators build positive relationships with others, get rid of external control, choose the best solutions, and live happily to create an effective life [25].

An important characteristic of a normal personality is the individual's sense of responsibility. This responsibility can be responsibility for himself or herself and the institution in which he or she works. Also, it can be responsibility for his or her colleagues, friends, neighbors, and other individuals with whom he or she is being in touch.

And if every individual in society feels personal responsibility towards himself or herself, other individuals, and the work he or she does, the society will get advanced and prosperous. A normal person who feels personal responsibility always helps others [16].

By reviewing educational literature, researchers found some studies that dealt with the variables of the current study. Beesley \& Frey [13] study aimed to identify the principals' realizations of school psychological counselors' roles and satisfaction with school counseling services in the United States of America. The sample of the study comprised (303) male and female Principals. The results of the study showed that the general satisfaction of the principals with the provided counseling services varied across the (primary, intermediate, preparatory, and secondary) levels and the service area.

Al-A'nabkey [1] conducted a study that aimed at identifying the responsibility and self-consistency of the educational counselors. He identified the differences in the correlation between responsibility and the self-consistency of the educational counselors following the gender variable. The sample of the study comprised (150) female and male counselors in secondary schools in the Baghdad Governorate. The results of the study showed that educational counselors are characterized by responsibility and self-consistency. The results, also, showed a positive correlation between responsibility and self-consistency among educational counselors. The absence of the difference in the relationship between the two criteria among the counselors following the gender variable is displayed.

TAIT [37] conducted a study that aimed at identifying the counselors' realizations regarding their roles in transitional services for learning disabled students towards post-secondary education. The study sample comprised (500) trustworthy principals in the United States of America. The results of the study showed the weakness of secondary school counselors' realization of their roles as they do not see themselves as having a primary role in working with learning disabled individuals in the post-secondary transition.

Al- Darraji [3] conducted a study that pointed at identifying the counseling responsibility, moral commitment, and automatic rulings of the self among the educational counselors. Besides, it highlighted the correlation between these three variables among the educational counselors following the gender and duration of service variables. The sample of the study comprised (400) male and female counselors, in the Baghdad Governorate, who was chosen by the stratified random method. The results of the study showed that educational counselors have counseling responsibility above the average rating. Also, the results showed that there is a difference in personal responsibility following the gender variable that went for the females. Besides, there is a difference in the relationship between counseling responsibility and moral commitment following the gender variable to be in favor of the females. The relationship between the study variables is interactive, and its effect is mutual and dissimilar.

The study of Ali \& Dawood [5] aimed to scale the personal responsibility of educational counselors, identifying the differences in personal responsibility following the gender variable. The sample of the study comprised (367) female and male counselors, in Baghdad Governorate, who were randomly selected. The results of the study showed that educational counselors have personal responsibility. Also, the results showed that there is a statistically significant difference in the personal responsibility of the educational counselors because of the gender variable to go for the females.

Mohsen [29] conducted a study that aimed at identifying the level of realization of the role and self-realization of the psychological counselors. Besides, it pointed out the differences following the gender and duration of the service variables. The sample of the study comprised (300) male and female counselors working in secondary schools (intermediate and preparatory schools) in the Baghdad Governorate. They were randomly selected. The results of the study set forth that psychological counselors have a role realization and a realization of themselves. Also, the results showed that there are statistically significant differences between the role realization and self-realization of the psychological counselors following the gender variable to be in favor of the males. Concerning the service period variable, there are statistically significant differences between the role realization and self-realization of the psychological counselors to go for more than (10) years. The results also showed a statistically significant correlation between role realization and self-realization 
among psychological counselors.

El-Shuwaili [18] conducted a study that aimed at identifying the emotional knowledge and responsibility of the educational counselors. Besides, it highlighted the differences in the emotional knowledge and responsibility of the educational counselors following the gender variable. The sample of the study comprised (400) male and female counselors in Baghdad Governorate, who were chosen in a random stratified manner. The results of the study showed that educational counselors possess high emotional and responsible knowledge. Besides, the results showed that there is a statistically significant difference between the emotional knowledge and responsibility of the counselors following the gender variable to be in favor of the females. The results also showed a correlation between emotional knowledge and responsibility among educational counselors.

It is noticed from the previous presentation that the current study is one of the few studies that attempted to identify the level of role realization and personal responsibility of the trainee counselors. The first study, within the limits of the researchers' knowledge, brought together the two variables of the role realization and personal responsibility of the trainee counselors. Also, this study tried to pinpoint the effect of the academic achievement variable on the role realization and personal responsibility of the trainee counselors which is not being discussed in previous studies. The researchers have availed from previous studies such as defining the theoretical framework, directing the track of the current study to define the problem. Also, they help the researchers determine the method used, variables that will be addressed, and the aspects that will be covered in the study.

\section{The Study Questions}

The researchers are university instructors at the counseling and educational psychology department and field training supervisors of psychological counseling students. The researchers noted through field visits, following up on the practical aspects of the trainee counselors in the school, that the trainee counselors perform irrelevant tasks to the educational counselors' ones. This negatively affects their role and the level of their performance in counseling situations. The psychological counselors' role realization gives them the ability to effectively maintain and implement a comprehensive counseling program to meet the school counselors' needs. Therefore, any failure in perceiving the role of the psychological counselors may lead them to a lack of self-confidence and a sense of unreliability. This may negatively affect their thoughts, self-consideration, and behaviors. Besides, it may affect their taking the responsibility imposed on them, their sensitivity towards their success in performing their duties properly, and their relationship with others.
Hence, the problem of the current study is determined by its attempt to identify the level of role realization and its relationship with the personal responsibility of the counselors. Also, it attempted to shed light on the differences regarding the level of role realization and personal responsibility following the academic achievement variable.

The current study tried to answer the following questions:

1) What is the level of role realization among trainee counselors?

2) Does the level of the role realization of the trainee counselors differ following the academic achievement variable?

3) What is the level of personal responsibility of the trainee counselors?

4) Does the level of personal responsibility of the trainee counselors differ following the academic achievement variable?

5) Is there a correlation between the role realization and the personal responsibility of the trainee counselors?

\section{The Study Significance}

The following highlights the importance of the current study:

\subsection{Theoretical Significance}

The current study represents special importance for researchers because of the scarcity of interest in studies in this field, within the limits of researchers' knowledge. The researchers noted, through their review of previous studies, that most of them was interested in understanding the role and responsibility separately and not linking both in a joint study. Thus, this study is the first attempt to study the role realization and its relationship to the personal responsibility of the trainee counselors at Yarmouk University.

\subsection{Significance}

The significance of the current study stems from helping students realize their counseling role that enhances their concept of personal responsibility towards their contacts with the counselors in schools. The importance of the study applicably lies in displaying some recommendations to provide those in charge of the trainee's field program with feedback. The importance of the study is also highlighted by the researchers' development of the role-realization metrics for the trainee counselors, allowing researchers to benefit from it to achieve educational objectives outside the current study. 


\section{Procedural Terms}

\subsection{Role Realization}

It is the specific expectations that are shaped an individual sees himself or herself and helps him or her determine the behaviors he or she should perform and the behaviors to be avoided [23]. It is procedurally defined as the total score got by the respondent on the used scale of role realization in the current study.

\subsection{Responsibility}

It is the ability to achieve an individual's needs in a way that does not deprive others of their ability to achieve their needs and their rights. And the responsible person is independent and has a sense of latent ability to determine what he or she wants from life and satisfy his or her needs and objectives responsibly [20]. And it is procedurally defined as the total score got by the respondent on the used scale of personal responsibility in the current study.

Trainee counselor: He or she is the student who is expected to graduate from the Bachelor of Psychological Counseling program. He or she is a trainee in a school under the supervision of the cooperative educational counselor and the trainee supervisor field.

\subsection{Academic Achievement}

It is the knowledge that the trainee counselor acquired during his or her learning of a specific topic. It is a group of scientific investigations that he learned in a semester, school year, or academic stage.

\section{Method and Procedures}

\subsection{Study Community}

The study population comprised all undergraduate students at Yarmouk University who were enrolled in a training course in psychological counseling. They were in the first and second semesters of the academic year 2019/2020. They were (162) male and female students following the statistics of the Admission and Registration Department at Yarmouk University.

\subsection{The Study Sample}

The sample of the study comprised (132) male and female students, who were chosen randomly and intentionally. Table (1) shows the distribution of the members of the study sample following the variable of academic achievement.

Table 1. Distribution of the study sample following the academic achievement variable

\begin{tabular}{cccc}
\hline Variable & Categories & Frequency & Percentage \\
\hline $\begin{array}{c}\text { Academic } \\
\text { Achievement }\end{array}$ & $\begin{array}{c}\text { Good and } \\
\text { Less } \\
\text { Very Good } \\
\text { and more }\end{array}$ & 65 & 49.2 \\
\hline \multicolumn{2}{r}{ Total } & $\mathbf{1 3 2}$ & $\mathbf{1 0 0 . 0}$ \\
\hline
\end{tabular}

\section{Study Instruments}

\subsection{Role Realization Scale}

The researchers developed the role realization scale by taking advantage of the tasks and duties of the educational advisor in the Jordanian Ministry of Education, which is the primary source to build the study instrument. The scale shall be in its primary form, from (26) items.

\subsection{Scale Validity}

The researchers presented the scale in its primary form, comprising (26) items to (10) referees with specialization in the domain of psychological counseling, educational psychology, measurement, and evaluation. To judge the validity, accuracy, and clarity of the items, and the degree of affiliation of each item to the scale as a whole, and observations regarding the integrity of the linguistic wording of the items were taken, and the scale remained in its final form comprising (26) items.

Indicators of constructing validity were extracted for all items of the study scale, by applying it to an exploratory sample consisting of (30) male and female students, from the study community and from outside the study sample. Two criteria were accepted to accept the items: Correlation Coefficient $(0.30)$ or more and the statistical significance of the correlation. The calculation of correlation coefficients between each item and the scale as a whole and all correlation coefficients between each of the items and the scale as a whole was statistically significant as table (2) illustrates this.

It appears from Table (2) that all correlation coefficients between each of the items and the overall scale were statistically significant. And the correlation coefficients between the items and the overall scale ranged from $(0.44)$ to $(0.81)$ which are acceptable for applying the current study. 
Table 2. Correlation Coefficients between each item and the overall scale

\begin{tabular}{|c|c|c|c|c|c|}
\hline Item Number & $\begin{array}{c}\text { Correlation } \\
\text { Coefficient with the } \\
\text { instrument }\end{array}$ & Item Number & $\begin{array}{c}\text { Correlation } \\
\text { Coefficient with } \\
\text { the instrument }\end{array}$ & Item Number & $\begin{array}{l}\text { Correlation Coefficient } \\
\text { with the instrument }\end{array}$ \\
\hline 1 & $(* *) 0.77$ & 10 & $(* *) 0.59$ & 19 & $(* *) 0.81$ \\
\hline 2 & $(* *) 0.64$ & 11 & $(* *) 0.69$ & 20 & $(* *) 0.77$ \\
\hline 3 & $(* *) 0.63$ & 12 & $(* *) 0.76$ & 21 & $(* *) 0.56$ \\
\hline 4 & $(* *) 0.49$ & 13 & $(* *) 0.76$ & 22 & $(* *) 0.62$ \\
\hline 5 & $(* *) 0.71$ & 14 & $(* *) 0.63$ & 23 & $(* *) 0.62$ \\
\hline 6 & $(* *) 0.59$ & 15 & $(* *) 0.67$ & 24 & $(* *) 0.65$ \\
\hline 7 & $(* *) 0.76$ & 16 & $(*) 0.44$ & 25 & $(* *) 0.81$ \\
\hline 8 & $(* *) 0.70$ & 17 & $(* *) 0.66$ & 26 & $(* *) 0.75$ \\
\hline 9 & $.670(* *)$ & 18 & $(* *) 0.58$ & & \\
\hline
\end{tabular}

*Statistically significant at the level of significance $(0.05) . * *$ Statistically significant at the level of significance $(0.01)$.

\subsection{Scale Reliability}

To verify the reliability of the scale, the researchers applied it to a survey sample comprising (30) male and female students from the study community and from outside it. The scale was re-applied to the same sample two weeks after the first application. The reliability of the scale was calculated by the Test-Re-Test method by using the Person-R correlation coefficient between the first application and the second application. The "reliability constancy" got (89). The internal consistency coefficient of Cronbach Alpha was also calculated to reach (78).

\subsection{Scale Correction}

The scale comprised, in its final form, of (26) items on a scale with a five-point answer, which takes the following weights. (5) degrees are given for " it applies to me completely". (4) degrees are for " it applies to me a lot". (3) degrees are given for " it applies to me intermediately". (2) degrees are for " it applies to me very little" and (1) degree for "it never applies to me." The overall trainee counselors' degrees ranged from (26) to (130). The following classification was used to determine the arithmetic means. From (2.33 or less) was "low", from (2.34) to (3.66) was "average", and from (3.67 or more) was "high".

\section{The Scale of Personal Responsibility}

In the present study, the researchers used the scale of personal responsibility prepared by Ali and Ahmed (2016) which comprised (24) items.

\subsection{Scale Validity}

Ali \& Ahmed [5] verified the validity of the scale through apparent honesty. They displayed the scale to specialists who were asked to express their opinions on the clarity of the linguistic wording. Indicators of constructing validity were extracted from all items of the study scale. And all correlation coefficients between each of the items and the scale as a whole were statistically significant and ranged from (0.330) to (0.531).

To ensure the accuracy of the scale in the current study, it was presented to (10) referees specialized in psychological counseling, educational psychology, measurement, and evaluation. The referees judge the extent of clarity and linguistic integrity, the extent to which each item belongs to the scale as a whole, and the results of the arbitration concluded. They alter some linguistic formulations, delete one item, and the number of items of the scale in its ultimate form became (23) items.

Indicators of the validity of construction were extracted for all items of the study scale, by applying it to an exploratory sample comprising (30) male and female students, from the study community and from outside the study sample, where two criteria were accepted to accept the items: correlation coefficient $(0.30)$ or more, The statistical significance of the correlation, and the calculation of correlation coefficients between each item and the scale as a whole, and all correlation coefficients between each of the items and the scale as a whole were statistically significant, and Table (3) illustrates this. 
Table 3. Correlation coefficients between each item and the overall scale

\begin{tabular}{|c|c|c|c|c|c|}
\hline Item Number & $\begin{array}{c}\text { Correlation } \\
\text { Coefficient with the } \\
\text { instrument }\end{array}$ & Item Number & $\begin{array}{c}\text { Correlation } \\
\text { Coefficient with } \\
\text { the instrument }\end{array}$ & Item Number & $\begin{array}{c}\text { Correlation } \\
\text { Coefficient with the } \\
\text { instrument }\end{array}$ \\
\hline 1 & $(* *) 0.49$ & 10 & $(* *) 0.58$ & 19 & $(* *) 0.76$ \\
\hline 2 & $(* *) 0.67$ & 11 & $(* *) 0.53$ & 20 & $(* *) 0.71$ \\
\hline 3 & $(*) 0.38$ & 12 & $(* *) 0.58$ & 21 & $(* *) 0.77$ \\
\hline 4 & $(* *) 0.58$ & 13 & $(* *) 0.73$ & 22 & $(*) 0.39$ \\
\hline 5 & $(* *) 0.72$ & 14 & $(* *) 0.71$ & 23 & $(* *) 0.53$ \\
\hline 6 & $(* *) 0.62$ & 15 & $(* *) 0.54$ & 24 & $(* *) 0.71$ \\
\hline 7 & $(* *) 0.56$ & 16 & $(* *) 0.76$ & 25 & (*)0.38 \\
\hline 8 & $(* *) 0.67$ & 17 & $(* *) 0.82$ & 26 & $(* *) 0.76$ \\
\hline 9 & $(* *) 0.49$ & 18 & $(* *) 0.58$ & & \\
\hline
\end{tabular}

*Statistically significant at the level of significance $(0.05) .{ }^{* *}$ Statistically significant at the level of significance $(0.01)$.

Table (3) shows that all correlation coefficients between each of the items and the overall scale were statistically significant, and the correlation coefficients between the items and the overall scale ranged between (0.38-0.82), which are acceptable for applying the current study.

\subsection{Scale Reliability}

Concerning the scales of stability of the scale, Ali and Ahmed (2016) calculated the internal consistency coefficient Cronbach Alpha and reached (0.807), as well as the stability of the re-test using a test-re-test method, and (0.84).

To verify the stability of the scale in the current study, the researchers applied it to a survey sample comprising (30) male and female students from the study community and from outside the study sample, and the scale was re-applied to the same sample two weeks after the first application, following the stability of the scale by testing and re-testing (Test-Re-Test) by calculating the Person-R correlation coefficient between the first application and the second application, "stability", reached (90). The internal consistency factor Cronbach Alpha was calculated, and it reached (81).

\subsection{Scale Correction}

The scale is in its final form of (23) items with a five-step answer, which takes the following weights: (5) degrees apply to me completely, (4) degrees apply to me, and (4) degrees apply to me, to a medium degree (3) degrees, and a few degrees apply to me, and two degrees do not apply to me Never take one degree. The total exam score on the scale ranged from (23) to (115). The following classification was used to judge the arithmetic mean: $(2.33$ or less) got a low rating degree, (2.34-3.66) got an average, and (3.67 or more) got high.

\subsection{Study variables}

The study included three variables, academic achievement and has two levels (very good and above, and good or less), role realization, and personal responsibility of the trainee counselors.

\section{Study Methodology}

The nature of this study required the descriptive-analytical approach, which depends on the study of the phenomenon in reality as it exists, and is interested in as accurately and expressing quantitatively and qualitatively, and contributes to the classification and organization of information, and to reaching conclusions that contribute to the realization of the level of realization of the role and personal responsibility of the trainee counselors and the relationship between them.

\section{The Study Results and Discussion}

\subsection{First: Results Related to the First Question: What is the Level of Role Realization among Trainee Counselors?}

To answer this question, Arithmetic means and standard deviations were extracted for the level of role realization of the trainee counselors as follows 
Table 4. Arithmetic means and Standard Deviations of Items Related to Level of Realization of trainee counselors

\begin{tabular}{|c|c|c|c|c|c|}
\hline The Rank & $\begin{array}{c}\text { Item } \\
\text { Number }\end{array}$ & Item & Arithmetic means & $\begin{array}{c}\text { Standard } \\
\text { Deviations }\end{array}$ & Level \\
\hline 1 & 18 & $\begin{array}{l}\text { I write informative information in private } \\
\text { records and keep it confidential. }\end{array}$ & 4.36 & 0.830 & High \\
\hline 2 & 7 & $\begin{array}{l}\text { I direct students towards proper behaviors } \\
\text { and habits }\end{array}$ & 4.30 & 0.720 & High \\
\hline 3 & 2 & $\begin{array}{l}\text { I ensure that I instill the ethical and } \\
\text { instructional values within students. }\end{array}$ & 4.28 & 0.745 & High \\
\hline 4 & 4 & $\begin{array}{l}\text { I provide students with information about } \\
\text { areas of specialization and what suits them. }\end{array}$ & 4.17 & 0.875 & High \\
\hline 5 & 8 & $\begin{array}{l}\text { Learn about students' inclinations, abilities, } \\
\text { aptitudes, and aids in their development }\end{array}$ & 4.16 & 0.799 & High \\
\hline 6 & 9 & $\begin{array}{l}\text { I am working to make students aware of the } \\
\text { magnificent study and study methods. }\end{array}$ & 4.10 & 0.818 & High \\
\hline 7 & 6 & $\begin{array}{c}\text { I inform students about their rights and } \\
\text { duties considering school standards and } \\
\text { instructions. }\end{array}$ & 4.09 & 0.903 & High \\
\hline 8 & 25 & $\begin{array}{l}\text { I help students eliminate the negative effects } \\
\text { of exam anxiety. }\end{array}$ & 4.08 & 0.825 & High \\
\hline 9 & 19 & $\begin{array}{l}\text { I do a comprehensive survey of students' } \\
\text { problems and include them in the indicative } \\
\text { plan to address them or reduce their effects. }\end{array}$ & 3.97 & 0.965 & High \\
\hline 10 & 1 & $\begin{array}{l}\text { I get sure to educate students and gain } \\
\text { insight into the best ways to protect them } \\
\text { from psychological and social problems and } \\
\text { disorders. }\end{array}$ & 3.95 & 0.898 & High \\
\hline 11 & 11 & $\begin{array}{l}\text { I instruct students on how to prepare for } \\
\text { school exams. }\end{array}$ & 3.95 & 0.809 & High \\
\hline 12 & 3 & $\begin{array}{l}\text { I help new students align with the school } \\
\text { environment. }\end{array}$ & 3.93 & 0.858 & High \\
\hline 13 & 12 & $\begin{array}{l}\text { I am correcting the students' wrong } \\
\text { behaviors. }\end{array}$ & 3.92 & 0.847 & High \\
\hline 14 & 20 & $\begin{array}{l}\text { I conduct a case study of problems that do } \\
\text { not end with one or two interviews for their } \\
\text { depth and comprehensiveness. }\end{array}$ & 3.92 & 0.962 & High \\
\hline 15 & 17 & $\begin{array}{l}\text { I hold collective counseling sessions for } \\
\text { some students. }\end{array}$ & 3.89 & 0.959 & High \\
\hline 16 & 16 & $\begin{array}{l}\text { I monitor student absences and learn their } \\
\text { causes. }\end{array}$ & 3.83 & 1.052 & High \\
\hline 17 & 10 & $\begin{array}{l}\text { I diagnose negative phenomena in students } \\
\text { and work to treat or reduce them. }\end{array}$ & 3.76 & 0.839 & High \\
\hline 18 & 22 & $\begin{array}{l}\text { I cooperate with the students' parents in } \\
\text { solving their children's problems and } \\
\text { counseling them on the correct ways of } \\
\text { dealing with them. }\end{array}$ & 3.71 & 1.015 & High \\
\hline 19 & 24 & $\begin{array}{l}\text { I cooperate with the administration to } \\
\text { prepare preventive programs to address } \\
\text { students' problems. }\end{array}$ & 3.60 & 1.111 & Average \\
\hline 20 & 14 & $\begin{array}{l}\text { I provide support to students with special } \\
\text { needs, especially those with vision and } \\
\text { hearing impairments. }\end{array}$ & 3.50 & 1.109 & Average \\
\hline 21 & 26 & $\begin{array}{l}\text { I help teachers discover students' } \\
\text { psychological incompatibilities from the } \\
\text { beginning. }\end{array}$ & 3.47 & 0.961 & Average \\
\hline 22 & 13 & $\begin{array}{l}\text { I recognize the gifted and talented students } \\
\text { and strive to develop their abilities and } \\
\text { talents. }\end{array}$ & 3.39 & 1.103 & Average \\
\hline 23 & 15 & $\begin{array}{l}\text { I apply psychological tests to help students } \\
\text { understand themselves. }\end{array}$ & 3.30 & 1.024 & Average \\
\hline 24 & 23 & $\begin{array}{l}\text { I am doing some research and studies on } \\
\text { educational problems and developing the } \\
\text { counseling process. }\end{array}$ & 3.17 & 1.149 & Average \\
\hline 25 & 5 & $\begin{array}{l}\text { I take part in faculty and administrative } \\
\text { meetings to provide a clear vision of the } \\
\text { most important students 'problems and plans } \\
\text { to address them. }\end{array}$ & 3.06 & 1.209 & Average \\
\hline 26 & 21 & $\begin{array}{l}\text { I am forming a school counseling } \\
\text { committee. }\end{array}$ & 3.02 & 1.136 & Average \\
\hline \multicolumn{3}{|r|}{ Total Degree } & 3.80 & 0.583 & High \\
\hline
\end{tabular}


Table (4) shows that the Arithmetic means ranged from (3.02) to (4.36). Item (18) "I write informative information in private records and keep it confidential" was in the first rank with an average (4.36) and a high level. However, item (21) "I am forming the school counseling committee" got the last rank with an average score of (3.02) and an average level. The arithmetic means of the scale for the role realization as a whole was (3.80) and got a high level. The reason is that the trainee counselors have reached a good level of role realization because of cumulative experiences. The role realization is affected by factors related to the psychological counselor's knowledge of his or her capabilities and personal characteristics that enable him or her to realize his or her tasks and responsibilities. These tasks can care for others with a conscience, understanding the emotions of others, and expressing sympathy with them. Thus, they are seeking to develop realistic human relations between the counselors and the counselees. The role realization is the principal component of personal and social success. The trainee counselor's role realization also enhances the individual's realization of the behaviors required for competence, determining the individual's constructive role through a set of specific expectations. Understanding the roles and functions of the counselor helps provide the best counseling services for the counselees. It enables others to understand the nature of the counselor's role and the counseling work, cooperating with the counselor to perform duties and accurately evaluate this performance [10]. This finding is consistent with the results of Mohsen's [29] study, which indicated that psychologists have a role realization for others and realization for themselves. This result differs from the results of the TAIT [37] study which showed the weakness of secondary school counselors' realization of their roles.

\subsection{Second: The Results Related to the Second Question: Does the Level of Role Realization among the Trainee Counselors Differ Following the Academic Achievement Variable?}

To answer this question, arithmetic means and standard deviations were extracted for the level of realization of the trainee counselors following the academic achievement variable. To show the statistical differences among the arithmetic mean, the "T" Test was used. Table (5) illustrates this.

Table (5) shows that there were no statistically significant differences at the level $(\alpha=0.05)$. The researchers justify this result by referring to the effect of academic achievement on the scale of role realization as a whole among the trainee counselors. This may be attributed to the fact that all trainee counselors, regardless of their academic achievement, need to know their roles and realize them to carry out their tasks and responsibilities and depend on themselves in making their decisions, and their growing ability to perceive the problems of the counselees and take care of them and listen to them, and their understanding of the individual differences of the counselees, and knowing the level of their capabilities, points of strength and weakness which did not show differences between them. The researchers show the absence of differences in the averages of the overall degree of the role realization following the academic achievement variable. The reason is that the trainee counsrlors' awareness of their roles helps them achieve their tasks effectively. It positively reflected on overcoming the difference between trainee counselors with a "very good or higher academic qualification" and "good or less". Thus, they possessed similar levels of role realization, considering that all trainee counselors, regardless of their academic achievement, because they have received the same qualification and training same.

\subsection{Third: Results Related to the Third Question: What is the Level of Personal Responsibility among Trainee Counselors?}

To answer this question, averages and standard deviations for the level of personal responsibility among the trainee counselors were extracted as table 6 .

Table 5. Arithmetic means, standard deviations, and T-Test for the impact of academic achievement on the level of role realization among trainee counselors

\begin{tabular}{|c|c|c|c|c|c|c|c|}
\hline Variable & Categories & Number & $\begin{array}{c}\text { Arithmetic } \\
\text { means }\end{array}$ & $\begin{array}{c}\text { Standard } \\
\text { Deviations }\end{array}$ & T Value & $\begin{array}{l}\text { Freedom } \\
\text { Degrees }\end{array}$ & $\begin{array}{c}\text { Statistical } \\
\text { Significance }\end{array}$ \\
\hline & Accepted and less & 65 & 3.90 & 0.501 & \multirow[b]{2}{*}{1.877} & \multirow[b]{2}{*}{130} & \multirow[b]{2}{*}{.0630} \\
\hline $\begin{array}{c}\text { Role } \\
\text { Realization }\end{array}$ & $\begin{array}{l}\text { Very good and } \\
\text { more }\end{array}$ & 67 & 3.71 & .6430 & & & \\
\hline
\end{tabular}


Table 6. Arithmetic means and standard deviations for the items related to the level of personal responsibility among the trainee counselors

\begin{tabular}{|c|c|c|c|c|c|}
\hline The Rank & Item Number & Item & Arithmetic means & $\begin{array}{c}\text { Standard } \\
\text { Deviations }\end{array}$ & Level \\
\hline 1 & 14 & I hand over deposits to their owners. & 4.73 & 0.511 & High \\
\hline 2 & 16 & I keep the counselees' secrets. & 4.70 & 0.576 & High \\
\hline 3 & 21 & I preserve the school property. & 4.66 & 0.590 & High \\
\hline 4 & 17 & $\begin{array}{l}\text { I get sure to fulfill my obligations with the } \\
\text { counselees. }\end{array}$ & 4.61 & 0.563 & High \\
\hline 5 & 23 & I attend school regularly. & 4.60 & 0.616 & High \\
\hline 6 & 20 & I respect the counselees' ideas & 4.57 & 0.555 & High \\
\hline 7 & 9 & I care about the counselees' feelings. & 4.54 & 0.647 & High \\
\hline 8 & 18 & I help everyone who needs me. & 4.52 & 0.599 & High \\
\hline 9 & 22 & I preserve order in the school. & 4.52 & 0.671 & High \\
\hline 10 & 3 & $\begin{array}{l}\text { I bear the consequences of my actions and } \\
\text { actions. }\end{array}$ & 4.45 & 0.724 & High \\
\hline 11 & 11 & $\begin{array}{l}\text { I care about the value of the things I am } \\
\text { responsible for. }\end{array}$ & 4.45 & 0.680 & High \\
\hline 12 & 2 & I keep my appointments strictly. & 4.41 & 0.709 & High \\
\hline 13 & 15 & $\begin{array}{l}\text { I direct students to maintain personal and } \\
\text { school hygiene. }\end{array}$ & 4.41 & 0.761 & High \\
\hline 14 & 10 & I make sure to build my future for myself. & 4.39 & 0.639 & High \\
\hline 15 & 6 & I keep counseling records. & 4.34 & 0.770 & High \\
\hline 16 & 19 & $\begin{array}{l}\text { I get sure to solve the problems of } \\
\text { counselees. }\end{array}$ & 4.33 & 0.662 & High \\
\hline 17 & 7 & $\begin{array}{l}\text { I am interested in constantly developing } \\
\text { myself. }\end{array}$ & 4.30 & 0.749 & High \\
\hline 18 & 13 & I master the work assigned to it. & 4.29 & 0.726 & High \\
\hline 19 & 1 & I do my work perfectly. & 4.25 & 0.724 & High \\
\hline 20 & 4 & I feel remorse when I shorten my duties. & 4.20 & 0.863 & High \\
\hline 21 & 8 & $\begin{array}{l}\text { I rely on myself to solve my problems at } \\
\text { work. }\end{array}$ & 4.18 & 0.750 & High \\
\hline 22 & 12 & I repair the damaged things. & 4.11 & 0.840 & High \\
\hline \multirow[t]{2}{*}{23} & 5 & I constantly check the students' conditions. & 3.94 & 0.827 & High \\
\hline & & Total Degree & 4.41 & .4060 & |High \\
\hline
\end{tabular}

Table (6) shows that the arithmetic means ranged from (3.94) to (4.73). Item (14) "I hand over deposits to their owners" came first with an average of 4.73 and a high level. However, item (5) "I constantly check the students' conditions" came last with an average of (3.94) and a high level. The mean of the scale of personal responsibility as a whole was (4.41) and with a high level. The reason for that is the first Trainee counselors, at the school, think about how they perform the duties assigned to them, such as learning about students' problems and their psychological and social needs. This is a sign that the Trainee counselors assume personal responsibility. They can satisfy their needs in responsible ways without depriving others of their needs. They carry out their duties and responsibilities towards themselves and others. They can choose the best behavior, evaluate it, control it, and those responsible for it, making appropriate decisions, and communicate with others. Personal responsibility is a manifestation of mental health. The Trainee counselors have reached a good level of responsibility because of cumulative experiences, focusing their energies on the behaviors that qualify them to take personal responsibility. Personal responsibility helps educators build positive relationships with others, get rid of outside control, and choose the best solutions and live happily to create an effective life [25]. Besides, The concept of responsibility also clearly affects the achievement of success and the feeling of happiness among counselors who adopt responsible behaviors that lead them to success and progress [11]. Personal responsibility is the essence of counseling in reality as the educator who bears personal responsibility is an independent person who has internal psychological support to determine what he or she wants from life. Responsibility assists the individual in choosing an optimal behavior and self-determination [9]. This result is consistent with the results of the studies of Al-Anbaki [1] and Ali \& Dawood [5] which showed that educational counselors are characterized by taking responsibility. Besides, it matches with the results of the Al-Darraji [3] study that showed that educational counselors have an indicative responsibility with an above-average rate. Also, it agrees with the results of a study El-Shuwaili [18] which indicated that educational 
counselors are highly responsible.

10.4 Fourth: Results Related to the Fourth Question: Does the Level of Personal Responsibility among the Trainee Counselors Differ Following the Academic Achievement Variable?

To answer this question, Arithmetic means and standard deviations for the level of personal responsibility of the trainee counselors were extracted following the academic achievement variable; and to show the statistical differences between the arithmetic means, the " $\mathrm{T}$ " Test was used, as is shown in table (7).

Table (7) shows that there were no statistically significant differences at the level $(\alpha=0.05)$. The researchers justify this result by referring to the effect of academic achievement on the scale of personal responsibility as a whole among the trainee counselors. This can be explained because the first thing that the trainee counselors think about is to know the nature of the counselees so that the counselees would not carelessly treat them. This is a good sign that the trainee counselors have personal responsibility. And it makes them able to continue their extension work well. The acquisition of personal responsibility is not exclusive to a specific class. The development opportunities are the same for all groups of trainee counselors, regardless of the level of academic achievement. The researchers also justify this result as the trainee counselors possess similar levels of personal responsibility regardless of academic achievement. All trainee counsellors, of all levels of academic achievement, need to possess personal responsibility in their counseling work. Personal responsibility is a basic and primary skill that every trainee counselors must possess in the counseling field.

\subsection{Fifth: Results Related to the Fifth Question: Is There a Correlation between the Role Realization and Personal Responsibility among the Trainee Counselors?}

To answer this question, the Pearson Correlation Coefficient between the role realization and the personal responsibility of the Trainee counselors was extracted as table 8 .

Table (8) sets forth that there is a positive (direct) relationship statistically between the role realization and the personal responsibility of the trainee counselors. Trainee counselors can recognize their roles and prepare to take responsibility for fulfilling these roles. The relationship between the two variables is direct, meaning that the more awareness the trainee counselor has about his or her role, the higher his or her responsibility is.

\section{The Study Determinants}

The study included the following determinants

The current study was limited to all undergraduate students at Yarmouk University who are enrolled in a field training course in psychological counseling. The researchers conducted the study in the first and second semesters of the academic year 2019/2020. The results of this study are also determined by the sample respondents' responses to the two items of the study instruments: The role realization and the personal responsibility scales. The researchers included the validity and reliability indications in this study.

Table 7. Arithmetic means, standard deviations, and a T-Test for the impact of academic achievement on the level of personal responsibility among trainee counselors

\begin{tabular}{ccccccc}
\hline Variable & Categories & Number & $\begin{array}{c}\text { Arithmetic } \\
\text { means }\end{array}$ & $\begin{array}{c}\text { Standard } \\
\text { Deviations }\end{array}$ & $\begin{array}{c}\text { T Value } \\
\text { Freedom } \\
\text { Degrees }\end{array}$ & $\begin{array}{c}\text { Statistical } \\
\text { Significance }\end{array}$ \\
\hline $\begin{array}{c}\text { Personal } \\
\text { Responsibility }\end{array}$ & Accepted and less & 65 & 4.46 & 0.381 & $\mathbf{1 . 3 3 8}$ & $\mathbf{1 3 0}$ \\
\hline
\end{tabular}

Table 8. Pearson Correlation Coefficient of the relationship between the role realization and the personal responsibility of the Trainee counselors

\begin{tabular}{ccc}
\hline Scale & Pearson Correlation Coefficient & Statistical Significance \\
\hline Role Realization Scale & $(* *) 0.629$ & 0.000 \\
Personal Responsibility Scale & & \\
\hline
\end{tabular}

* Statistically significant at the level of significance (0.05). ** Statistically significant at the level of significance (0.01). 


\section{Conclusions}

The realization of trainee counselors' roles is one of the most important components in the domain of counseling. Also, it plays a fundamental role in the trainee counselors' performance which helps them provide counseling services for the counselees. And it enables others to understand the nature of the role of the counselor and counseling. Also, the counselors' realization of their roles helps maintain the counseling program, meet the needs of the trainees, and develop the counselors' self-confidence and sense of stability. This may be positively reflected on the counselors in terms of their responsibility, commitment, and sense of success by correctly performing the tasks assigned to them. These factors contribute to the integrity of the trainee counselors' personality. The results showed that the levels of the role realization and personal responsibility of the trainee counselors were at a high level. And there was no statistically significant difference between the levels of the role realization and personal responsibility because of the academic achievement variable. Besides, the results showed the existence of a statistically significant positive relationship between the role realization and personal responsibility of the trainee counselors. The researchers believe that future researchers will avail from this study by conducting different other variables on the same topic.

\section{Recommendations}

Considering the context of the results, the researchers recommend:

- Paying attention to preparing the trainee counselors to increase their efficiency in the advisory work.

- Organizing training courses for the trainee counselors to highlight the importance of personal responsibility and its reflection on the counselors' performance and mastery of the counseling profession.

- Conducting more studies on the personal responsibility of the trainee counselors and its relationship to other variables.

- Conducting studies on other variables related to role realization, such as personality style and self-efficacy.

- Developing counseling programs for trainee counselors that contribute to developing their responsibility.

\section{REFERENCES}

[1] Al-A'nabki, Ahlam, "Taking responsibility and its relationship to the consistency of the educational counselors", (Unpublished Master Thesis). Iraq: Al-Mustansiriya University, 2009.

[2] Al-Ashqar, Celt Rose, "The eldest son has a distinguished face", translated by Khalil Ahmed Khalil, Beirut: Lebanese House of Thought, 1997.

[3] Al-Darraji, Zainab, "Counseling responsibility, moral commitment, and their relationship to automatic rulings on the self of educational counselors", (Unpublished Doctoral Thesis), Iraq: University of Baghdad, 2016.

[4] Al-Dosari, Salma, "Designing a scale of social responsibility for members of society in protecting and preserving the environment permanently and continuously", Journal of Studies in Social Work and Humanities, No. 9, pp. 366-393, 2000.

[5] Ali, Olahen, Dawood Ahmad, "Personal responsibility for educational counselors", Nasaq Magazine, Vol. 9, pp.79-104, 2016.

[6] Al-Khawaja, Abdel Fattah, "Psychological and educational counseling between theory and practice, responsibilities and duties, the guide for parents and counselees", Amman: House of Culture for Publishing and Distribution, 2009.

[7] Al-Meligi, Helmi, "Personal psychology", Cairo: Arab Renaissance House, 2001.

[8] Al-Rashidi, Bashir, "Psychological counseling following realistic therapy", Kuwait: Injaz International Group for Publishing and Distribution, 2005.

[9] Al-Tamimi, Mahmoud, "Cognitive psychology", Amman: Safa House for Publishing and Distribution, 2014.

[10] Al-Zaghalil, Ahmad, Al-Sharaa, Hussein, "The roles and instructional functions of the educational counselor in the Jordanian school and the difference in its practice according to gender, age, academic qualification, experience and specialization", Journal of the Center for Educational Research, Qatar University, Vol. 7, No.14, pp. 165-190, 1998.

[11] Al-Zayoud, Nader, "Theories of counseling and psychotherapy", Amman: Dar Al-Fikr for Printing and Publishing, 1998.

[12] Beena, C, Ramachandra Poduval, "Role conflict, role ambiguity, and role overload of women executives in organizations, (Doctoral Dissertation, Faculty of Social Sciences, Cochin University of Science and Technology, Kerala), 1999. DOI: 10.1.1.843.9573.

[13] Beesley, Denise; Frey Lisa L, "Principals' realizations of school counselor's roles and satisfaction with school counseling services", Journal of School Counseling, Vol. 4, No.14, pp. 1-27, 2006.

[14] Caldwell, Raymond, "The changing roles of personnel managers: old ambiguities, new uncertainties", Journal of Management Studies, Vol. 40, No. 4, pp. 983-1004, 2003. DOI: 10.1111/1467-6486.00367.

[15] Dawood, Ahmad, "Personal responsibility and psychological resistance and their relationship to self-affirmation among educational counselors", (Unpublished Doctoral Thesis), Iraq: Al-Mustansiriya University, 2010.

[16] Dhiyab, Yousef, "Social responsibility guide. Palestine, Al-Quds Open University Publications, 2010.

[17] El- Shennawy, Mohammed, "Theories of counseling and 
psychotherapy", Riyadh: Gharib House for Publishing and Distribution, 1994.

[18] El-Shuwaili, Haider, "Emotional knowledge and its relationship to the responsibility of educational counselors", (Unpublished Master Thesis), Iraq: University of Baghdad, 2018 .

[19] Emmanuel, Donna, "Role realization of the pedagogical instructor from three points of view", In Z. Silberstein \& R. Reichenberg (Eds.), Renewed appraisal of the curriculum of specialization in pedagogic instruction, working paper, No. 2, pp. 69-106. Tel-Aviv: Mofet Institute (Hebrew), 2005.

[20] Glasser, William, "Reality therapy and choice therapy", Christian Discernment Publications Ministry, Inc, 1999.

[21] Hanna, Paul, "Trust yourself and do what you want", Riyadh: Jareer Bookstore for Publishing and Distribution, 2012.

[22] Hartenian, Linda, Hadaway Farran, Badovick Gordon, "Antecedents and consequences of role realizations: A path analytic approach", Journal of Applied Business Research (JABR), Vol. 10, No. 2, pp. 40-50, 1994.

[23] Katz, Daniel, Kahn Robert, "The social psychology of organizations", Second Edition, New York: John Wiley and Sons, 2003.

[24] Kazem, Abal, Horn Garry, "The role of educational counselors in Kuwait secondary school", Journal of Educational counseling, Vol. 8, pp. 333, 1995.

[25] Koh, E, "VWO applicants may, in conjunction with William Glaser Institute", 4-days basic intensive training, in Choice Theory \& Reality Therapy, New York, 2013.

[26] Madak, Paul, Gieni Carol, "Half-time elementary school counselors: Teachers' expectations of role versus actual activities", Canadian Journal of Counseling and Psychotherapy, Vol. 25, No. 3, pp. 317-330, 1991.

[27] Masharaf, Maisoon, "Moral thinking and its relationship to social responsibility and some variables among students of the Islamic University of Gaza", (Unpublished Master Thesis), Palestine: University of Gaza, 2009.
[28] McAllister, Daniel, Kamdar Dishan, Morrison Elizabeth, Turban Daniel, "Disentangling role realizations: How perceived role breadth, discretion, instrumentality, and efficacy related to helping and taking charge, Journal of Applied Psychology, Vol. 92, No. 5, pp. 1200- 1211, 2007. DOI: 10.1037/0021-9010.92.5.1200.

[29] Mohsen, Asmaa, "Realization of the role and its relationship to self-realization among educational counselors", (Unpublished Master Thesis), Iraq: University of Baghdad, 2018.

[30] Perkins, M, "A short introduction to reality therapy and chicer theory", Email: map elves. Com, 2002.

[31] Reitzes, Donald, Mutran Elizabeth, "Multiple roles and identities: Factors influencing self-esteem among middle-aged working men and women", Social Psychology Quarterly, Vol. 57, No. 4, pp. 313-325, 1994. DOI: $10.2307 / 2787158$.

[32] Saha, Arpita, "Role expectations and realization", Retrieved February 23, 2020, from URL: http://ssrn.com/abstract=110 6548, 2008.

[33] Smadi, Ahmad, Athamneh Salah, "Development study for the scale of responsibility for Jordanian university students", The University of Sharjah Journal for Humanities and Social Sciences, Vol. 6, No. 3, pp. 273-298, 2008.

[34] St Brice, Hillman, "An Analysis of Role realizations and Job Satisfaction of Secondary-School Counselors in Trinidad and Tobago", 2001.

[35] Stets, Jan, Burke Peter, "Identity theory and social identity theory", Social Psychology Quarterly, Vol. 63, No. 3, pp. 224 -237, 2000. DOI: 10.2307/2695870.

[36] Tait, Molly, "Realizations of School Counselors Regarding Their Roles in Transition Services for Students with Learning Disabilities Towards Postsecondary Education (Doctoral dissertation", Texas Woman s University), 2013.

[37] Taylor, Shannon, Kluemper Donald, "Linking realizations of role stress and incivility to workplace aggression: The moderating role of personality". Journal of Occupational Health Psychology, Vol. 17, No. 3, pp. 316-329, 2012. 